\title{
Analiza przyczynowości i efekt zarażania na rynku obligacji skarbowych
}

Paweł Sekuła*

\section{Wstęp}

W ciaggu ostatnich kilkunastu lat koniunktura gospodarcza ulegała znacznym zmianom. Dużym wstrząsem było załamanie rynku nieruchomości w Stanach Zjednoczonych w latach 2007-2008, które wywołało światowy kryzys finansowy. Następstwem recesji w Europie okazał się kryzys zadłużenia w strefie euro. Wszystkie te zdarzenia zdeterminowały i zasadniczo zmieniły obraz rynku obligacji w Europie. W badanym okresie odnotowano znaczące wahania rynkowej wyceny długu oraz skrajnie wysokie i niskie poziomy rentowności obligacji skarbowych. W latach 2010-2012 europejski rynek instrumentów dłużnych borykał się z problemem spadku zaufania spowodowanym kryzysem greckim. Pojawił się mechanizm transmisji zmienności, tzw. efekt zarażania, w wyniku którego kryzys zadłużenia przenosił się z rynku jednego państwa na kolejne. Odpowiedzią na te problemy była zupełnie nowa polityka antykryzysowa - banki centralne zaczęły stosować niestandardowe instrumenty polityki pieniężnej, które doprowadziły do powstania wielu programów skupu obligacji na rynkach finansowych oraz historycznie niskich poziomów rynkowych stóp procentowych. Celem badania jest ocenienie zależności między zmianami rentowności długu skarbowego oraz wpływu kryzysu zadłużenia w strefie euro na relacje między badanymi rynkami obligacji.

Badania nad zależnościami na rynkach obligacji skarbowych państw europejskich obejmowały różne obszary. Część koncentrowała się na analizie interakcji między rynkiem długu rządowego a kondycją sektora finansowego (Ejsing, Lemke 2009; Gennaiolii i in. 2014). Przedmiotem licznych badań były też problemy tzw. zarażania między państwami w ramach strefy euro

* Paweł Sekuła - doktor, Uniwersytet Łódzki, Wydział Zarządzania, Katedra Zarządzania Finansami Przedsiębiorstwa, pawel.sekula@uni.lodz.pl 
(Kalbaska, Gatkowski 2012; Metiu 2012; Gorea, Radev 2014). Należy jednak podkreślić, że sama definicja zarażania budzi wątpliwości interpretacyjne - Burzała podaje trzy definicje o różnym zakresie szczegółowości. Najbardziej obszerna definicja odnosi się do międzynarodowej transmisji szoków lub ogólnie międzynarodowych skutków przepływu kapitału i dotyczy nie tylko kryzysu. Zarażanie w węższym zakresie jest rozumiane jako transmisja szoków na inne rynki wykraczająca poza fundamentalne powiązania i wspólne reakcje, a w najwęższym - jako silniejsza korelacja między rynkami w okresie kryzysu niż spokoju rynkowego (Burzała 2015). Definicje te pokazują, że proces może być analizowany i weryfikowany z kilku perspektyw - Kalbaska i Gatkowski (2012) analizowali dynamikę rynku swapów ryzyka kredytowego, Beetsma $\mathrm{i}$ in. skupili się poziomie wysokości premii na rynku długu wobec Niemiec i wpływie informacji. Podział wiadomości na złe i dobre pokazywał, że kładzenie nacisku na wzrost stóp procentowych było efektem złych wiadomości. Zauważono również, że złe wiadomości przenikały do innych państw, jednak skala skutków informacji była znacznie mniejsza w przypadku państw północy niż państw południa Europy (Beetsma i in. 2013). Metiu, który analizował relacje między spreadami obligacji skarbowych państw strefy euro w okresie od stycznia 2008 r. do lutego 2012 r., potwierdził występowanie znaczącego efektu domina, zwłaszcza w państwach południa Europy oraz w Belgii, oraz zaobserwował, że główne gospodarki strefy euro były mniej podatne na efekt zarażania (Metiu 2012). Bernoth i Erdogan analizowali rozpiętość rentowności obligacji skarbowych państw europejskich w okresie Q1 1999 - Q1 2010. Wskazywali oni na zmienność relacji w czasie - w trakcie kryzysu inwestorzy przywiązywali większą wagę do sytuacji fiskalnej poszczególnych państw, rosła też rola Niemiec jako miejsca bezpiecznej alokacji (Bernoth, Erdogan 2012). Maltritz, który badał determinanty spreadów rentowności obligacji skarbowych, zwracał uwagę na istotność wpływu bilansu handlowego, otwartości gospodarki, a przede wszystkim zmiennych fiskalnych takich jak deficyt budżetowy czy dług publiczny (Maltritz 2012). Bernoth i in., badając różnice w rentowności obligacji skarbowych w latach 1993-2009, zaobserwowali, że premie za ryzyko rosną wraz z zaburzeniami równowagi budżetowej i zależą negatywnie od wielkości rynku obligacji (Bernoth 2012). Afonso i in. skupili się na spreadach rentowności obligacji skarbowych w Europie w stosunku do obligacji Niemiec, by zauważyć znaczną zmienność w czasie oraz niestabilność istotnych determinant, których liczba rosła w okresie kryzysu (Afonso $i$ in. 2015). Arghyrou i Kontonikas, badając zachowanie obligacji skarbowych państw Europejskiej Unii Monetarnej (EMU), stwierdzili istotne zmiany po kryzysie z 2007 r. i wskazali na dowody zarażania, które dotyczyło głównie państw peryferyjnych EMU (Arghyrou, Kontonikas 2012). Karkowska analizowała wpływ zmienności rentowności obligacji greckich w czasie kryzysu 
zadłużenia, wykorzystując modele GARCH, i podkreślała wpływ kryzysu fiskalnego Grecji na poziom spreadu obligacji skarbowych (Karkowska 2015). Badanie związków w przypadku obligacji dotyczyło również zmian w korelacjach między rynkami (Syllignakis, Kouretas 2011) czy zmian w występowaniu i kierunku przyczynowości (Gomez-Puig, Sosvilla-Rivero 2014). Gomez-Puig i Sosvilla-Rivero analizowali przyczynowość oraz efekt zarażania na rynku obligacji skarbowych państw strefy euro. Kryzys sprawił, że pojawiło się 41 nowych wzorców przyczynowości, a związki przyczynowe nasiliły się w $70 \%$ badanych przypadków, co zdaniem badaczy dowodziło zarażenia w wyniku kryzysu zadłużenia w strefie euro. Powiązania między rentownościami obligacji skarbowych badali Babalos i in., wykorzystując nieliniowe metody analizy przyczynowości. Jeśli chodzi o okres 2000-2014, to potwierdzili oni dwukierunkowe relacje dla średniej i wariancji dla państw Europy Południowej oraz słabe relacje między rynkami na północy i południu. Zwracali także uwagę na przepływ informacji z krajów głównych do krajów peryferyjnych w Unii Europejskiej (Babalos i in. 2015). Wpływ globalizacji rynków finansowych na niezależność polityki pieniężnej i relacje między rynkami długu był przedmiotem analiz od wielu lat - badania nad oddziaływaniem zjawisk kryzysowych na stopień integracji prowadzono już na podstawie danych z lat 80. i 90. XX w. Testy wykazały wzmocnienie powiązań między obligacjami skarbowymi Niemiec, Stanów Zjednoczonych i Wielkiej Brytanii w okresie napięć na rynkach finansowych (Clare, Lekkos 2000). Badając relacje na rynku obligacji, analizowano wpływ poziomu integracji finansowej i podawano dowody na silne powiązania między rynkami obligacji strefy euro a rynkiem niemieckim. Podkreślano również występowanie w tamtym okresie znacznie słabszych relacji w przypadku nowych rynków UE: Czech, Polski, Węgier i Wielkiej Brytanii. Ogólnie stopień integracji tych rynków był niski i stabilny (Kim i in. 2005). W przypadku Czech, Polski i Węgier testowano również efekt zarażania i poziom integracji w czasie kryzysu finansowego w 2008 r. Stwierdzono, że kryzys finansowy miał największy wpływ na węgierski rynek finansowy, a najmniejszy - na rynek czeski. Jeśli chodzi o Polskę, to była ona na początku kryzysu traktowana jako kraj o wyższym poziomie ryzyka niż Czechy, dlatego negatywna transmisja szoków do Polski była silniejsza. W badaniach podkreślano, że dobra kondycja gospodarki może zmniejszyć siłę oddziaływania szoków (Bieńkowski i in. 2011).

Zdefiniowany cel badawczy i obserwacje przebiegu koniunktury w analizowanym okresie pozwoliły na postawienie dwóch hipotez badawczych.

H1: „Występują istotne zależności przyczynowe w sensie Grangera między rynkami obligacji skarbowych w Europie".

H2: „W czasie kryzysu zadłużenia w strefie euro nastąpił efekt transmisji zmian rentowności na rynkach obligacji skarbowych". 


\section{Opis próby i metoda badawcza}

Badania relacji na europejskim rynku obligacji dotyczyły analizy zależności w sensie Grangera oraz efektu zarażania. Zarówno w jednym, jak i w drugim przypadku wykorzystano tę samą grupę państw - przeanalizowano pochodzące $\mathrm{z}$ serwisu stooq dane dotyczące szeregów czasowych rentowności dziesięcioletnich obligacji skarbowych właściwych dla Belgii (BE), Czech (CZ), Niemiec (DE), Hiszpanii (ES), Finlandii (FI), Francji (FR), Grecji (GR), Węgier (HU), Włoch (IT), Niderlandów (NL), Polski (PL) i Szwecji (SE). W badaniu wykorzystano pełniące kluczową rolę na rynkach finansowych obligacje dziesięcioletnie, ponieważ to zwykle na nich koncentrują się największa podaż i popyt, a ponadto są one instrumentem bazowym dla derywatów na długoterminowe stopy procentowe. W pracy przyjęto zatem, że obligacje dziesięcioletnie mogą odzwierciedlać tendencje rynkowe i bieżącą ocenę długu danego państwa przez inwestorów. Wybór obligacji dziesięcioletnich jako instrumentów referencyjnych był zgodny z metodyką Eurostatu opartą na kryterium stóp procentowych z Maastricht.

Analizowane szeregi czasowe zmiennych pochodziły z okresu styczeń 2006 - grudzień 2018, a dane były publikowane w odstępach tygodniowych, co dało to łącznie 680 obserwacji. W badanym okresie poziomy zmiennych znacząco się wahały. W tym czasie miały również miejsce istotne dla gospodarki światowej zdarzenia, które zdeterminowały politykę pieniężną i fiskalną, wpływając na koniunkturę na rynkach instrumentów dłużnych. W 2008 r. w państwach europejskich rozpoczął się poważny kryzys gospodarczy i finansowy spowodowany załamaniem koniunktury na rynku hipotecznym w Stanach Zjednoczonych. Aktywa na rynkach finansowych uległy silnej przecenie, a koniunktura gospodarcza gwałtownie się pogorszyła. Ujawniły się także skutki niekorzystnych zjawisk, które miały miejsce we wcześniejszych latach: problemy wynikające ze zbyt wysokiego długu publicznego niektórych państw, nadmierne inwestycje w nieruchomości i instrumenty finansowe, zbyt wysoka dźwignia finansowa w systemie bankowym, spekulacyjne wzrosty cen aktywów.

Następstwem kryzysu z 2008 r. był kryzys zadłużenia państw w strefie euro. Obawy o zdolność do obsługi długu przez Grecję (2010) wywołały reakcję łańcuchową i narastające wątpliwości co do innych państw, a to doprowadziło do znacznych wahań cen obligacji państw europejskich. Decydenci, aby przeciwdziałać zjawiskom kryzysowym i ustabilizować sytuację, przedefiniowali dotychczasową politykę i zaczęli stosować niestandardowe metody - w ramach tzw. nowej polityki pieniężnej uruchomiono szereg wielokrotnie wznawianych programów płynnościowych i pożyczkowych. Programy skupu aktywów miały istotny wpływ na rynek obligacji, przyczyniając się m.in. 
do wystąpienia po raz pierwszy ujemnych rentowności obligacji niektórych państw. Koniunkturę na rynkach obligacji obrazuje Wykres 1. We wszystkich badanych krajach, poza Grecją, obserwowano długoterminowy spadek rentowności obligacji dziesięcioletnich, co było skutkiem antykryzysowej polityki pieniężnej. Skala spadków rentowności obligacji była powiązana z poziomem ratingu inwestycyjnego (Tabela 5, załącznik) - w przypadku państw o najwyższym ratingu odnotowano nawet wartości ujemne (DE, NL) lub bliskie zeru (FI, SE). Znaczący wzrost rentowności obligacji miał natomiast miejsce w okresie tzw. kryzysu greckiego. Grecja i państwa oceniane jako bardziej ryzykowne doświadczyły wówczas gwałtownego wzrostu wymaganej rentowności - w kulminacyjnym momencie kryzysu dziesięcioletnie obligacje greckie były notowane na rynkach przy wymaganej rentowności powyżej $35 \%$. Wyraźny wzrost rentowności obligacji dotyczył również rynków obligacji Hiszpanii, Włoch i Węgier, a krótkoterminowy - Belgii.

Wykres 1. Rentowność dziesięcioletnich obligacji skarbowych w latach 2006-2018
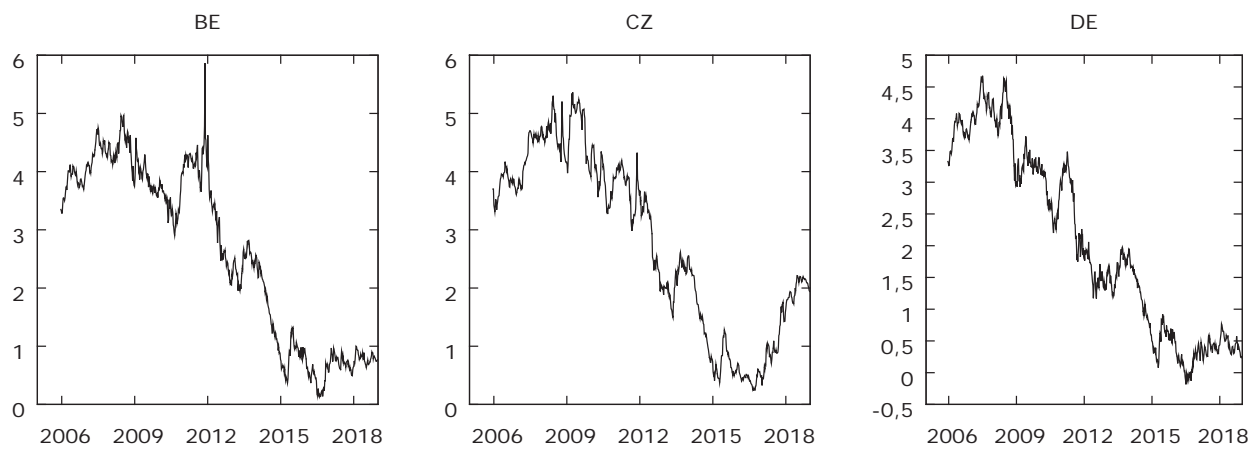

ES
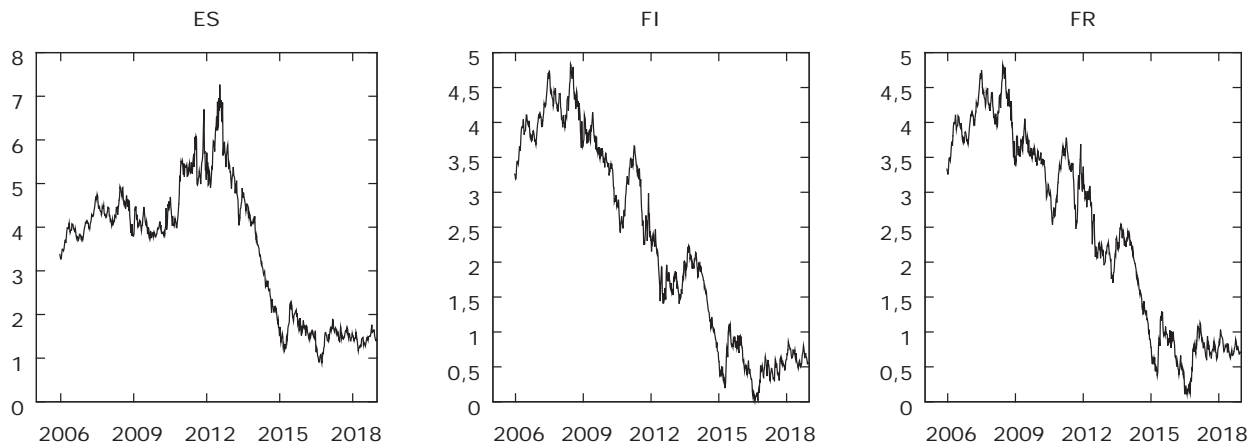
GR

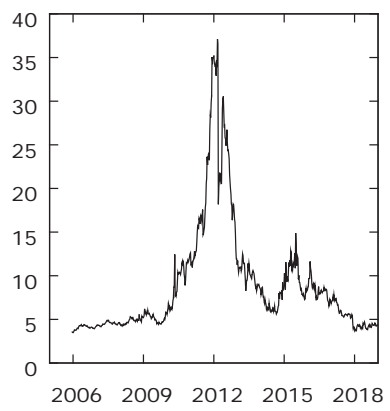

$\mathrm{NL}$

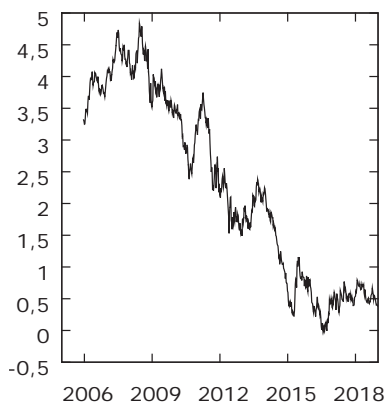

$\mathrm{HU}$

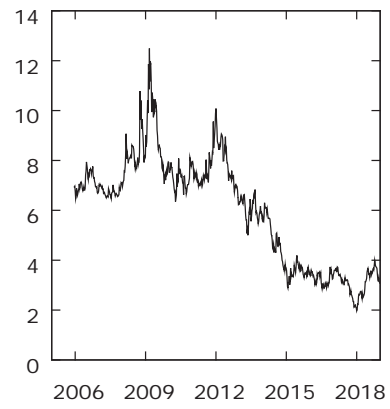

PL

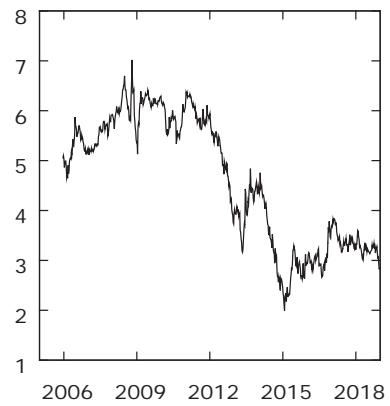

IT

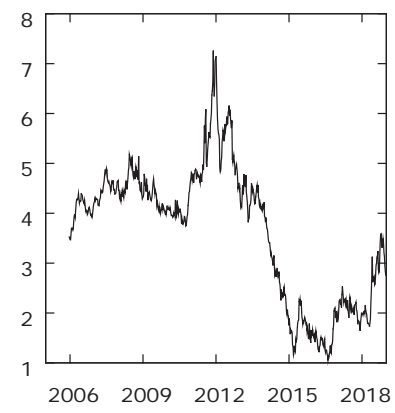

SE

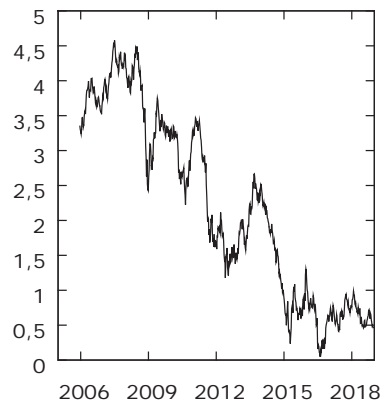

Źródło: opracowanie własne.

Charakterystyki opisowe badanych szeregów czasowych zamieszczono w Tabeli 1. Z cotygodniowych analiz informacji o poziomie rentowności dziesięcioletnich obligacji skarbowych wynikało, że charakteryzował się on dużą zmiennością. Najwyższe współczynniki zmienności odnotowano w przypadku Grecji oraz Niemiec, Niderlandów, Finlandii i Szwecji, co oznaczało, że przyczyną zmienności były nie tylko problemy ekonomiczne, jak w przypadku Grecji, lecz również polityka pieniężna, która doprowadziła do znaczących spadków rentowności, zwłaszcza w przypadku państw z wysokimi ratingami inwestycyjnymi. Szeregi danych wykazywały asymetrię rozkładu. Państwa z największą zmiennością charakteryzowały się rozkładami prawostronnie asymetrycznymi, w pozostałych przypadkach wystąpiły rozkłady lewostronnie asymetryczne. W analizowanych szeregach dominowały rozkłady platokurtyczne, czyli o mniejszej koncentracji niż rozkład normalny. Tylko w przypadku Grecji wystąpił rozkład leptokurtyczny.

Analizując przyczynowość w sensie Grangera, wykorzystano przekształcone dane rynkowe. Badaniu poddano tygodniowe procentowe zmiany rentowności obligacji dziesięcioletnich, obliczone na podstawie wzoru $\left(r_{t}-r_{t-1}\right) /\left|r_{t-1}\right|$, gdzie $r_{t}$ odpowiadało rentowności obligacji w tygodniu $t$. 
Tabela 1. Statystyki opisowe zmiennych na podstawie obserwacji tygodniowych w latach 2006-2018

\begin{tabular}{|l|c|c|r|r|c|c|c|c|}
\hline Zmienna & Średnia & Mediana & Min & Max & $\begin{array}{c}\text { Odchyle- } \\
\text { nie stand. }\end{array}$ & $\begin{array}{c}\text { Wspól. } \\
\text { zmienności }\end{array}$ & Skośność & Kurtoza \\
\hline BE & 2,6206 & 2,8595 & 0,1299 & 5,8630 & 1,5074 & 0,5752 & $-0,2059$ & $-1,5282$ \\
\hline CZ & 2,7613 & 2,9990 & 0,2440 & 5,3650 & 1,5172 & 0,5494 & $-0,1306$ & $-1,3555$ \\
\hline DE & 2,0518 & 1,7870 & $-0,1842$ & 4,6770 & 1,4520 & 0,7077 & 0,1666 & $-1,4179$ \\
\hline ES & 3,4984 & 3,9490 & 0,8880 & 7,2670 & 1,5336 & 0,4384 & $-0,1062$ & $-1,1235$ \\
\hline FI & 2,2648 & 2,0985 & 0,0200 & 4,8360 & 1,4526 & 0,6414 & 0,0710 & $-1,4793$ \\
\hline FR & 2,4356 & 2,5155 & 0,1091 & 4,8250 & 1,3783 & 0,5659 & $-0,0949$ & $-1,4401$ \\
\hline GR & 8,9135 & 6,6600 & 3,4840 & 37,1010 & 6,4558 & 0,7243 & 2,2405 & 5,1553 \\
\hline HU & 6,0024 & 6,6400 & 1,9700 & 12,4700 & 2,1894 & 0,3648 & $-0,0195$ & $-0,8797$ \\
\hline IT & 3,6408 & 4,0735 & 1,0510 & 7,2610 & 1,3509 & 0,3710 & $-0,2163$ & $-0,8149$ \\
\hline NL & 2,2673 & 2,1835 & $-0,0080$ & 4,8380 & 1,4613 & 0,6445 & 0,0389 & $-1,4632$ \\
\hline PL & 4,6000 & 4,9145 & 1,9900 & 7,0190 & 1,2906 & 0,2806 & $-0,1750$ & $-1,4806$ \\
\hline SE & 2,1955 & 2,0370 & 0,0470 & 4,5780 & 1,3118 & 0,5975 & 0,1183 & $-1,3738$ \\
\hline
\end{tabular}

Źródło: opracowanie własne.

W kolejnym etapie badania przeprowadzono dwa testy: ADF i KPSS. Pierwszy z nich weryfikuje hipotezę zerową, zgodnie z którą występuje pierwiastek jednostkowy - szereg jest niestacjonarny (Dickey, Fuller 1979). W przypadku badanych poziomów zmiennych statystyki testu ADF były niższe od wartości krytycznych, co pozwoliło na odrzucenie hipotezy zerowej. Test KPSS zakłada natomiast w hipotezie zerowej stacjonarność badanego szeregu zmiennych (Kwiatkowski i in. 1992) i jego wyniki nie dały podstaw do odrzucenia hipotezy zerowej.

Tabela 2. Wyniki testów ADF i KPSS

\begin{tabular}{|c|c|c|c|}
\hline \multirow{3}{*}{ Zmienna } & \multicolumn{2}{|c|}{ ADF test } & \multirow{2}{*}{$\begin{array}{c}\text { KPSS test } \\
\text { Wartość krytyczna } \\
(\alpha=0,05) 0,462(\alpha=0,01) 0,742\end{array}$} \\
\hline & \multicolumn{2}{|c|}{ Poziom zmiennych } & \\
\hline & Statystyka testu & $p$ & Statystyka testu \\
\hline \multicolumn{4}{|c|}{ okres 2006-2018 } \\
\hline BE & $-6,9343$ & 0,0000 & 0,1127 \\
\hline $\mathbf{C Z}$ & $-8,3250$ & 0,0000 & 0,1698 \\
\hline DE & $-8,1540$ & 0,0000 & 0,0824 \\
\hline ES & $-7,3560$ & 0,0000 & 0,1179 \\
\hline FI & $-6,2737$ & 0,0000 & 0,3557 \\
\hline FR & $-6,0766$ & 0,0000 & 0,1831 \\
\hline GR & $-6,8370$ & 0,0000 & 0,2882 \\
\hline HU & $-9,7775$ & 0,0000 & 0,0827 \\
\hline IT & $-7,3955$ & 0,0000 & 0,1021 \\
\hline NL & $-5,3547$ & 0,0000 & 0,4504 \\
\hline PL & $-6,5973$ & 0,0000 & 0,0805 \\
\hline SE & $-6,3469$ & 0,0000 & 0,1986 \\
\hline
\end{tabular}

Źródło: opracowanie własne. 
Testy ADF i KPSS potwierdziły, że wybór szeregów do badania przyczynowości między zmianami rentowności obligacji w różnych państwach był prawidłowy. Przez pojęcie ,przyczynowość w sensie Grangera” rozumie się, że zmienna $X$ jest przyczyną $Y$, jeżeli bieżące wartości $Y$ można dokładniej prognozować na podstawie przeszłych wartości $X$ (Granger 1969). W przypadku stacjonarnych szeregów czasowych przyczynowość w sensie Grangera badana jest przy użyciu modeli wektorowej autoregresji (VAR). Analizowane zależności opisywano następującym modelem VAR:

$$
\begin{gathered}
x_{K t}=a_{K 0}+\sum_{i=1}^{p} a_{K 1 i} x_{K t-i}+\sum_{i=1}^{p} a_{K 2 i} x_{L t-i}+\varepsilon_{K t} \\
x_{L t}=a_{L 0}+\sum_{i=1}^{p} a_{L 1 i} x_{L t-i}+\sum_{i=1}^{p} a_{L 2 i} x_{K t-i}+\varepsilon_{L t}
\end{gathered}
$$

$x_{K t} \quad-$ tygodniowa procentowa zmiana rentowności obligacji $K$,

$x_{L t} \quad-$ tygodniowa procentowa zmiana rentowności obligacji $L$,

$a_{K 0}, a_{L 0} \quad-$ wyrazy wolne,

$p \quad-$ rząd opóźnienia dla zmiennych $x_{K t}$ i $x_{L t}$,

$a_{K 1 i}, a_{K 2 i}, a_{L 1 i}, a_{K 2 i}$ - współczynniki określające zależności krótkoterminowe.

Testy liniowej przyczynowości Grangera przeprowadzono przy użyciu modeli VAR dla poszczególnych par zmiennych (Engle, Granger 1987).

Analiza efektu zarażania w czasie kryzysu zadłużeniowego państw Unii Europejskiej dotyczy okresu styczeń 2010 - grudzień 2013. Przedmiotem badania była rentowność dziesięcioletnich obligacji skarbowych 12 wybranych państw. Do analizy efektu zarażania wykorzystano dzienne, logarytmowane, procentowe zmiany poziomów rentowności obligacji. W przypadku dziesięciu państw estymowano modele dziennej zmienności rentowności obligacji; były to: Belgia (BE), Czechy (CZ), Hiszpania (ES), Finlandia (FI), Francja (FR), Węgry (HU), Włochy (IT), Niderlandy (NL), Polska (PL), Szwecja (SE). Nie stworzono modeli dla Niemiec (DE) i Grecji (GR), których szeregi czasowe były jedynie zmiennymi niezależnymi. Przyjęto, że Niemcy pełnią funkcję benchmarku dla europejskiego rynku długu, stanowiąc bezpieczną alternatywę w czasie kryzysu. W przypadku Grecji zakładano natomiast, że jest ona potencjalnym źródłem problemów i wzrostu zmienności na rynku obligacji. Dla każdego z szeregów czasowych wymienionych dziesięciu państw zbudowano uogólnione modele autoregresyjne warunkowej heteroskedastyczności GARCH $(1,1)$. Estymowano modele, w których na zmianę rentowności obligacji $\mathrm{w}$ dniu $t$ wpływały dzienne zmiany rentowności obligacji w dniu $t \mathrm{w}$ innych państwach oraz funkcja wariancji warunkowej. 


$$
\begin{gathered}
y_{t}=\alpha_{0}+\sum_{i=1}^{n} \alpha_{i} x_{i, t}+\xi_{t} \\
\xi_{t}=\vartheta_{t} \sqrt{h_{t}} \\
h_{t}=\gamma_{0}+\gamma_{1} \xi_{t-1}^{2} \phi_{1} h_{t-1}
\end{gathered}
$$

Gdzie $y_{t}$ oznaczało dzienną zmianę rentowności obligacji odpowiadającą zmiennej zależnej, $x_{t}$ - dzienną zmianę rentowności obligacji, która odpowiadała zmiennej niezależnej, $\vartheta_{t} \sim$ iid $(0,1)$, a $h_{t}$ oznaczało wariancję warunkową w dniu $t$. Dzienne zmiany rentowności obliczono według wzoru $\ln \left(r_{t} / r_{t-1}\right)$, gdzie $r_{t}$ odpowiadało rentowności obligacji $\mathrm{w}$ dniu $t$. Do modelowania wariancji warunkowej $h_{t}$ wykorzystano model GARCH $(1,1)$, w przypadku którego badania empiryczne dowiodły, że jeżeli $\grave{\gamma_{1}}+\dot{\phi}_{1}$ jest bliskie jedności, to zwykle możliwy jest dokładny opis modelowanych zjawisk finansowych (Brzeszyński, Klem 2002). Test oddziaływania zagranicznych rynków obligacji na rynek obligacji danego kraju polegał na weryfikacji hipotezy $x_{n 1}=\cdots=: x_{n n-1}=x_{n n+1}=\cdots=x_{n}=0$. W teście wykorzystano statystykę wiarygodności GARCH i Bayesowskie kryterium informacyjne. Jeśli wartość statystyki testu dawała podstawy do odrzucenia hipotezy, oznaczało to, że zmiana rentowności obligacji w danym kraju jest podatna na sygnały napływające z rynków obligacji innych państw.

\section{Wyniki analizy przyczynowości}

Badając współzależności między rynkami obligacji wybranych państw europejskich, w pierwszej kolejności przeprowadzono analizę przyczynowości w sensie Grangera między tygodniowymi zmianami procentowymi rentowności dziesięcioletnich obligacji skarbowych.

Przeanalizowano 66 par zmiennych, dla których estymowano modele VAR. Testy przyczynowości między zmianami rentowności obligacji potwierdziły występowanie 36 relacji dwukierunkowych i 20 relacji jednokierunkowych. W przypadku 10 par zmiennych testy modeli VAR nie potwierdziły relacji przyczynowych.

Wśród badanych zmiennych dominowały relacje dwukierunkowe, wskazujące na silne powiązania między poszczególnymi rynkami obligacji, co może oznaczać, że wpływ zależności finansowych i gospodarczych pomiędzy różnymi państwami był istotny. Brak relacji przyczynowych między zmiennymi dotyczył głównie tych par, w których występował rynek obligacji greckich. Wynikało to najprawdopodobniej z ryzyka specyficznego zmiennej GR. Kryzys zaufania do Grecji, obawy o możliwość obsługi długu oraz poważny kryzys 
gospodarczy i fiskalny powodowały, że czynniki zewnętrzne miały w badanym okresie bardzo ograniczony wpływ na rentowność greckich obligacji. Z drugiej strony oddziaływanie Grecji na inne państwa, również w okresie kryzysu, dotyczyło tylko części rynków. W przypadku zmiennych CZ, DE, FI, FR, NL, SE nie odnotowano żadnych istotnych relacji z rynkiem greckim, co może wskazywać, że rynki obligacji państw o wysokim ratingu inwestycyjnym były dość odporne na kryzys zadłużeniowy.

Tabela 3. Wyniki testów przyczynowości modeli VAR

\begin{tabular}{|c|c|c|c|}
\hline Przyczyna $\rightarrow$ Skutek & Wartość testu & Wartość $p$ & Wnioski \\
\hline $\mathrm{BE} \rightarrow \mathrm{CZ}$ & $F(10,648)=2,8163$ & $(0,0020)$ & relacja dwukierunkowa \\
\hline $\mathrm{CZ} \rightarrow \mathrm{BE}$ & $F(10,648)=2,7564$ & $(0,0025)$ & $\mathrm{BE} \leftrightarrow \mathrm{CZ}$ \\
\hline $\mathrm{BE} \rightarrow \mathrm{DE}$ & $F(10,648)=24,106$ & $(0,0000)$ & relacja dwukierunkowa \\
\hline $\mathrm{DE} \rightarrow \mathrm{BE}$ & $F(10,648)=8,2544$ & $(0,0000)$ & $\mathrm{BE} \leftrightarrow \mathrm{DE}$ \\
\hline $\mathrm{BE} \rightarrow \mathrm{ES}$ & $F(5,663)=3,3116$ & $(0,0058)$ & relacja jednokierunkowa \\
\hline $\mathrm{ES} \rightarrow \mathrm{BE}$ & $F(5,663)=1,5480$ & $(0,1728)$ & $\mathrm{BE} \rightarrow \mathrm{ES}$ \\
\hline $\mathrm{BE} \rightarrow \mathrm{FI}$ & $F(10,648)=16,103$ & $(0,0000)$ & relacja dwukierunkowa \\
\hline $\mathrm{FI} \rightarrow \mathrm{BE}$ & $F(10,648)=11,676$ & $(0,0000)$ & $\mathrm{BE} \leftrightarrow \mathrm{FI}$ \\
\hline $\mathrm{BE} \rightarrow \mathrm{FR}$ & $F(10,648)=8,5665$ & $(0,0000)$ & relacja dwukierunkowa \\
\hline $\mathrm{FR} \rightarrow \mathrm{BE}$ & $F(10,648)=9,8849$ & $(0,0000)$ & $\mathrm{BE} \leftrightarrow \mathrm{FR}$ \\
\hline $\mathrm{BE} \rightarrow \mathrm{GR}$ & $F(1,675)=0,8101$ & $(0,3684)$ & relacja jednokierunkowa \\
\hline $\mathrm{GR} \rightarrow \mathrm{BE}$ & $F(1,675)=6,2479$ & $(0,0127)$ & $\mathrm{GR} \rightarrow \mathrm{BE}$ \\
\hline $\mathrm{BE} \rightarrow \mathrm{HU}$ & $F(1,675)=11,232$ & $(0,0008)$ & relacja jednokierunkowa \\
\hline $\mathrm{HU} \rightarrow \mathrm{BE}$ & $F(1,675)=0,1723$ & $(0,6782)$ & $\mathrm{BE} \rightarrow \mathrm{HU}$ \\
\hline $\mathrm{BE} \rightarrow \mathrm{IT}$ & $F(5,663)=1,7228$ & $(0,1271)$ & relacja jednokierunkowa \\
\hline $\mathrm{IT} \rightarrow \mathrm{BE}$ & $F(5,663)=2,2588$ & $(0,0471)$ & $\mathrm{IT} \rightarrow \mathrm{BE}$ \\
\hline $\mathrm{BE} \rightarrow \mathrm{NL}$ & $F(10,648)=15,985$ & $(0,0000)$ & relacja dwukierunkowa \\
\hline $\mathrm{NL} \rightarrow \mathrm{BE}$ & $F(10,648)=15,633$ & $(0,0000)$ & $\mathrm{BE} \leftrightarrow \mathrm{NL}$ \\
\hline $\mathrm{BE} \rightarrow \mathrm{PL}$ & $F(5,663)=2,8645$ & $(0,0144)$ & relacja jednokierunkowa \\
\hline $\mathrm{PL} \rightarrow \mathrm{BE}$ & $F(5,663)=0,8674$ & $(0,5026)$ & $\mathrm{BE} \rightarrow \mathrm{PL}$ \\
\hline $\mathrm{BE} \rightarrow \mathrm{SE}$ & $F(10,648)=11,998$ & $(0,0000)$ & relacja dwukierunkowa \\
\hline $\mathrm{SE} \rightarrow \mathrm{BE}$ & $F(10,648)=19,205$ & $(0,0000)$ & $\mathrm{BE} \leftrightarrow \mathrm{SE}$ \\
\hline $\mathrm{CZ} \rightarrow \mathrm{DE}$ & $F(10,648)=6,1925$ & $(0,0000)$ & relacja jednokierunkowa \\
\hline $\mathrm{DE} \rightarrow \mathrm{CZ}$ & $F(10,648)=1,4572$ & $(0,1514)$ & $\mathrm{CZ} \rightarrow \mathrm{DE}$ \\
\hline $\mathrm{CZ} \rightarrow \mathrm{ES}$ & $F(10,648)=2,0568$ & $(0,0259)$ & relacja dwukierunkowa \\
\hline $\mathrm{ES} \rightarrow \mathrm{CZ}$ & $F(10,648)=6,0378$ & $(0,0000)$ & $\mathrm{CZ} \leftrightarrow \mathrm{ES}$ \\
\hline $\mathrm{CZ} \rightarrow \mathrm{FI}$ & $F(10,648)=4,6825$ & $(0,0000)$ & relacja dwukierunkowa \\
\hline $\mathrm{FI} \rightarrow \mathrm{CZ}$ & $F(10,648)=3,0970$ & $(0,0007)$ & $\mathrm{CZ} \leftrightarrow \mathrm{FI}$ \\
\hline $\mathrm{CZ} \rightarrow \mathrm{FR}$ & $F(10,648)=4,5422$ & $(0,0000)$ & relacja dwukierunkowa \\
\hline $\mathrm{FR} \rightarrow \mathrm{CZ}$ & $F(10,648)=2,4470$ & $(0,0072)$ & $\mathrm{CZ} \leftrightarrow \mathrm{FR}$ \\
\hline $\mathrm{CZ} \rightarrow \mathrm{GR}$ & $F(7,657)=1,9763$ & $(0,0560)$ & relacja jednokierunkowa \\
\hline $\mathrm{GR} \rightarrow \mathrm{CZ}$ & $F(7,657)=0,6924$ & $(0,0007)$ & $\mathrm{GR} \rightarrow \mathrm{CZ}$ \\
\hline $\mathrm{CZ} \rightarrow \mathrm{HU}$ & $F(7,657)=2,0924$ & $(0,0424)$ & relacja jednokierunkowa \\
\hline $\mathrm{HU} \rightarrow \mathrm{CZ}$ & $F(7,657)=1,7641$ & $(0,0917)$ & $\mathrm{CZ} \rightarrow \mathrm{HU}$ \\
\hline
\end{tabular}




\begin{tabular}{|c|c|c|c|}
\hline Przyczyna $\rightarrow$ Skutek & Wartość testu & Wartość $p$ & Wnioski \\
\hline $\mathrm{CZ} \rightarrow \mathrm{IT}$ & $F(10,648)=2,0717$ & $(0,0247)$ & relacja dwukierunkowa \\
\hline $\mathrm{IT} \rightarrow \mathrm{CZ}$ & $F(10,648)=4,0317$ & $(0,0000)$ & $\mathrm{CZ} \leftrightarrow \mathrm{IT}$ \\
\hline $\mathrm{CZ} \rightarrow \mathrm{NL}$ & $F(10,648)=3,0564$ & $(0,0008)$ & relacja dwukierunkowa \\
\hline $\mathrm{NL} \rightarrow \mathrm{CZ}$ & $F(10,648)=2,9680$ & $(0,0012)$ & $\mathrm{CZ} \leftrightarrow \mathrm{NL}$ \\
\hline $\mathrm{CZ} \rightarrow \mathrm{PL}$ & $F(7,657)=3,7603$ & $(0,0005)$ & relacja dwukierunkowa \\
\hline $\mathrm{PL} \rightarrow \mathrm{CZ}$ & $F(7,657)=3,4170$ & $(0,0013)$ & $\mathrm{CZ} \leftrightarrow \mathrm{PL}$ \\
\hline $\mathrm{CZ} \rightarrow \mathrm{SE}$ & $F(10,648)=2,2870$ & $(0,0123)$ & relacja dwukierunkowa \\
\hline $\mathrm{SE} \rightarrow \mathrm{CZ}$ & $F(10,648)=5,4715$ & $(0,0000)$ & $\mathrm{CZ} \leftrightarrow \mathrm{SE}$ \\
\hline $\mathrm{DE} \rightarrow \mathrm{ES}$ & $F(8,654)=2,2977$ & $(0,0197)$ & relacja dwukierunkowa \\
\hline $\mathrm{ES} \rightarrow \mathrm{DE}$ & $F(8,654)=4,6167$ & $(0,0000)$ & $\mathrm{DE} \leftrightarrow \mathrm{ES}$ \\
\hline $\mathrm{DE} \rightarrow \mathrm{FI}$ & $F(10,648)=23,622$ & $(0,0000)$ & relacja dwukierunkowa \\
\hline $\mathrm{FI} \rightarrow \mathrm{DE}$ & $F(10,648)=193,96$ & $(0,0000)$ & $\mathrm{DE} \leftrightarrow \mathrm{FI}$ \\
\hline $\mathrm{DE} \rightarrow \mathrm{FR}$ & $F(10,648)=3,8685$ & $(0,0000)$ & relacja dwukierunkowa \\
\hline $\mathrm{FR} \rightarrow \mathrm{DE}$ & $F(10,648)=40,336$ & $(0,0000)$ & $\mathrm{DE} \leftrightarrow \mathrm{FR}$ \\
\hline $\mathrm{DE} \rightarrow \mathrm{GR}$ & $F(5,663)=0,7973$ & $(0,5518)$ & brak relacji \\
\hline $\mathrm{GR} \rightarrow \mathrm{DE}$ & $F(5,663)=0,2172$ & $(0,9552)$ & $\mathrm{DE} \leftrightarrow \mathrm{GR}$ \\
\hline $\mathrm{DE} \rightarrow \mathrm{HU}$ & $F(5,663)=2,2881$ & $(0,0445)$ & relacja jednokierunkowa \\
\hline $\mathrm{HU} \rightarrow \mathrm{DE}$ & $F(5,663)=1,4290$ & $(0,2117)$ & $\mathrm{DE} \rightarrow \mathrm{HU}$ \\
\hline $\mathrm{DE} \rightarrow \mathrm{IT}$ & $F(5,663)=4,0345$ & $(0,0013)$ & relacja dwukierunkowa \\
\hline $\mathrm{IT} \rightarrow \mathrm{DE}$ & $F(5,663)=3,9033$ & $(0,0017)$ & $\mathrm{DE} \leftrightarrow \mathrm{IT}$ \\
\hline $\mathrm{DE} \rightarrow \mathrm{NL}$ & $F(10,648)=71,721$ & $(0,0000)$ & relacja dwukierunkowa \\
\hline $\mathrm{NL} \rightarrow \mathrm{DE}$ & $F(10,648)=115,75$ & $(0,0000)$ & $\mathrm{DE} \leftrightarrow \mathrm{NL}$ \\
\hline $\mathrm{DE} \rightarrow \mathrm{PL}$ & $F(5,663)=4,3647$ & $(0,0006)$ & relacja jednokierunkowa \\
\hline $\mathrm{PL} \rightarrow \mathrm{DE}$ & $F(5,663)=1,8222$ & $(0,1063)$ & $\mathrm{DE} \rightarrow \mathrm{PL}$ \\
\hline $\mathrm{DE} \rightarrow \mathrm{SE}$ & $F(10,648)=3,9844$ & $(0,0000)$ & relacja dwukierunkowa \\
\hline $\mathrm{SE} \rightarrow \mathrm{DE}$ & $F(10,648)=63,117$ & $(0,0000)$ & $\mathrm{DE} \leftrightarrow \mathrm{SE}$ \\
\hline $\mathrm{ES} \rightarrow \mathrm{FI}$ & $F(10,648)=4,0379$ & $(0,0000)$ & relacja dwukierunkowa \\
\hline $\mathrm{FI} \rightarrow \mathrm{ES}$ & $F(10,648)=2,3371$ & $(0,0104)$ & $\mathrm{ES} \leftrightarrow \mathrm{FI}$ \\
\hline $\mathrm{ES} \rightarrow \mathrm{FR}$ & $F(10,648)=3,7159$ & $(0,0001)$ & relacja dwukierunkowa \\
\hline $\mathrm{FR} \rightarrow \mathrm{ES}$ & $F(10,648)=2,3691$ & $(0,0093)$ & $\mathrm{ES} \leftrightarrow \mathrm{FR}$ \\
\hline $\mathrm{ES} \rightarrow \mathrm{GR}$ & $F(1,675)=0,0628$ & $(0,8023)$ & relacja jednokierunkowa \\
\hline $\mathrm{GR} \rightarrow \mathrm{ES}$ & $F(1,675)=4,6249$ & $(0,0319)$ & $\mathrm{GR} \rightarrow \mathrm{ES}$ \\
\hline $\mathrm{ES} \rightarrow \mathrm{HU}$ & $F(1,675)=6,3086$ & $(0,0122)$ & relacja jednokierunkowa \\
\hline $\mathrm{HU} \rightarrow \mathrm{ES}$ & $F(1,675)=0,9363$ & $(0,3336)$ & $\mathrm{ES} \rightarrow \mathrm{HU}$ \\
\hline $\mathrm{ES} \rightarrow \mathrm{IT}$ & $F(1,675)=0,1097$ & $(0,7406)$ & brak relacji \\
\hline $\mathrm{IT} \rightarrow \mathrm{ES}$ & $F(1,675)=0,3093$ & $(0,5783)$ & $\mathrm{ES} \leftrightarrow \mathrm{IT}$ \\
\hline $\mathrm{ES} \rightarrow \mathrm{NL}$ & $F(9,651)=6,1622$ & $(0,0000)$ & relacja dwukierunkowa \\
\hline $\mathrm{NL} \rightarrow \mathrm{ES}$ & $F(9,651)=2,1161$ & $(0,0263)$ & $\mathrm{ES} \leftrightarrow \mathrm{NL}$ \\
\hline $\mathrm{ES} \rightarrow \mathrm{PL}$ & $F(4,666)=4,0869$ & $(0,0028)$ & relacja dwukierunkowa \\
\hline $\mathrm{PL} \rightarrow \mathrm{ES}$ & $F(4,666)=2,5681$ & $(0,0370)$ & $\mathrm{ES} \leftrightarrow \mathrm{PL}$ \\
\hline $\mathrm{ES} \rightarrow \mathrm{SE}$ & $F(7,657)=4,8832$ & $(0,0000)$ & relacja dwukierunkowa \\
\hline $\mathrm{SE} \rightarrow \mathrm{ES}$ & $F(7,657)=2,5047$ & $(0,0152)$ & $\mathrm{ES} \leftrightarrow \mathrm{SE}$ \\
\hline $\mathrm{FI} \rightarrow \mathrm{FR}$ & $F(10,648)=11,007$ & $(0,0000)$ & relacja dwukierunkowa \\
\hline $\mathrm{FR} \rightarrow \mathrm{FI}$ & $F(10,648)=18,546$ & $(0,0000)$ & $\mathrm{FI} \leftrightarrow \mathrm{FR}$ \\
\hline
\end{tabular}


Tabela 3 (cd.)

\begin{tabular}{|c|c|c|c|}
\hline Przyczyna $\rightarrow$ Skutek & Wartość testu & Wartość $p$ & Wnioski \\
\hline $\mathrm{FI} \rightarrow \mathrm{GR}$ & $F(10,648)=0,3300$ & $(0,9731)$ & brak relacji \\
\hline $\mathrm{GR} \rightarrow \mathrm{FI}$ & $F(10,648)=0,4107$ & $(0,9418)$ & $\mathrm{FI} \leftrightarrow \mathrm{GR}$ \\
\hline $\mathrm{FI} \rightarrow \mathrm{HU}$ & $F(10,648)=1,7439$ & $(0,0677)$ & brak relacji \\
\hline $\mathrm{HU} \rightarrow \mathrm{FI}$ & $F(10,648)=0,7410$ & $(0,6860)$ & $\mathrm{FI} \leftrightarrow \mathrm{HU}$ \\
\hline $\mathrm{FI} \rightarrow \mathrm{IT}$ & $F(10,648)=3,1520$ & $(0,0006)$ & relacja dwukierunkowa \\
\hline $\mathrm{IT} \rightarrow \mathrm{FI}$ & $F(10,648)=2,1038$ & $(0,0223)$ & $\mathrm{FI} \leftrightarrow \mathrm{IT}$ \\
\hline $\mathrm{FI} \rightarrow \mathrm{NL}$ & $F(10,648)=59,202$ & $(0,0000)$ & relacja dwukierunkowa \\
\hline $\mathrm{NL} \rightarrow \mathrm{FI}$ & $F(10,648)=156,27$ & $(0,0000)$ & $\mathrm{FI} \leftrightarrow \mathrm{NL}$ \\
\hline $\mathrm{FI} \rightarrow \mathrm{PL}$ & $F(10,648)=3,0488$ & $(0,0009)$ & relacja jednokierunkowa \\
\hline $\mathrm{PL} \rightarrow \mathrm{FI}$ & $F(10,648)=1,1703$ & $(0,3078)$ & $\mathrm{FI} \rightarrow \mathrm{PL}$ \\
\hline $\mathrm{FI} \rightarrow \mathrm{SE}$ & $F(10,648)=9,8597$ & $(0,0000)$ & relacja dwukierunkowa \\
\hline $\mathrm{SE} \rightarrow \mathrm{FI}$ & $F(10,648)=15,919$ & $(0,0000)$ & $\mathrm{FI} \leftrightarrow \mathrm{SE}$ \\
\hline $\mathrm{FR} \rightarrow \mathrm{GR}$ & $F(5,663)=0,5366$ & $(0,7486)$ & brak relacji \\
\hline $\mathrm{GR} \rightarrow \mathrm{FR}$ & $F(5,663)=1,6905$ & $(0,1346)$ & $\mathrm{FR} \leftrightarrow \mathrm{GR}$ \\
\hline $\mathrm{FR} \rightarrow \mathrm{HU}$ & $F(10,648)=2,6194$ & $(0,0040)$ & relacja jednokierunkowa \\
\hline $\mathrm{HU} \rightarrow \mathrm{FR}$ & $F(10,648)=0,6697$ & $(0,7531)$ & $\mathrm{FR} \rightarrow \mathrm{HU}$ \\
\hline $\mathrm{FR} \rightarrow \mathrm{IT}$ & $F(10,648)=2,5140$ & $(0,0057)$ & relacja dwukierunkowa \\
\hline $\mathrm{IT} \rightarrow \mathrm{FR}$ & $F(10,648)=4,1311$ & $(0,0000)$ & $\mathrm{FR} \leftrightarrow \mathrm{IT}$ \\
\hline $\mathrm{FR} \rightarrow \mathrm{NL}$ & $F(10,648)=25,881$ & $(0,0000)$ & relacja dwukierunkowa \\
\hline $\mathrm{NL} \rightarrow \mathrm{FR}$ & $F(10,648)=27,882$ & $(0,0000)$ & $\mathrm{FR} \leftrightarrow \mathrm{NL}$ \\
\hline $\mathrm{FR} \rightarrow \mathrm{PL}$ & $F(10,648)=3,8187$ & $(0,0000)$ & relacja jednokierunkowa \\
\hline $\mathrm{PL} \rightarrow \mathrm{FR}$ & $F(10,648)=1,3684$ & $(0,1908)$ & $\mathrm{FR} \rightarrow \mathrm{PL}$ \\
\hline $\mathrm{FR} \rightarrow \mathrm{SE}$ & $F(10,648)=18,623$ & $(0,0000)$ & relacja dwukierunkowa \\
\hline $\mathrm{SE} \rightarrow \mathrm{FR}$ & $F(10,648)=17,337$ & $(0,0000)$ & $\mathrm{FR} \leftrightarrow \mathrm{SE}$ \\
\hline $\mathrm{GR} \rightarrow \mathrm{HU}$ & $F(1,675)=0,1276$ & $(0,7211)$ & brak relacji \\
\hline $\mathrm{HU} \rightarrow \mathrm{GR}$ & $F(1,675)=0,1405$ & $(0,7079)$ & $\mathrm{GR} \leftrightarrow \mathrm{HU}$ \\
\hline $\mathrm{GR} \rightarrow \mathrm{IT}$ & $F(1,675)=8,6393$ & $(0,0034)$ & relacja jednokierunkowa \\
\hline $\mathrm{IT} \rightarrow \mathrm{GR}$ & $F(1,675)=0,5644$ & $(0,4527)$ & $\mathrm{GR} \rightarrow \mathrm{IT}$ \\
\hline $\mathrm{GR} \rightarrow \mathrm{NL}$ & $F(9,651)=0,3913$ & $(0,9395)$ & brak relacji \\
\hline $\mathrm{NL} \rightarrow \mathrm{GR}$ & $F(9,651)=0,2508$ & $(0,9865)$ & $\mathrm{GR} \leftrightarrow \mathrm{NL}$ \\
\hline $\mathrm{GR} \rightarrow \mathrm{PL}$ & $F(1,675)=0,3423$ & $(0,5587)$ & brak relacji \\
\hline $\mathrm{PL} \rightarrow \mathrm{GR}$ & $F(1,675)=0,1707$ & $(0,6796)$ & $\mathrm{GR} \leftrightarrow \mathrm{PL}$ \\
\hline $\mathrm{GR} \rightarrow \mathrm{SE}$ & $F(1,675)=2,1298$ & $(0,1449)$ & brak relacji \\
\hline $\mathrm{SE} \rightarrow \mathrm{GR}$ & $F(1,675)=0,0008$ & $(0,9771)$ & $\mathrm{GR} \leftrightarrow \mathrm{SE}$ \\
\hline $\mathrm{HU} \rightarrow \mathrm{IT}$ & $F(1,675)=3,1867$ & $(0,0747)$ & relacja jednokierunkowa \\
\hline $\mathrm{IT} \rightarrow \mathrm{HU}$ & $F(1,675)=12,904$ & $(0,0004)$ & $\mathrm{IT} \rightarrow \mathrm{HU}$ \\
\hline $\mathrm{HU} \rightarrow \mathrm{NL}$ & $F(9,651)=1,4692$ & $(0,1555)$ & brak relacji \\
\hline $\mathrm{NL} \rightarrow \mathrm{HU}$ & $F(9,651)=1,2029$ & $(0,2900)$ & $\mathrm{HU} \leftrightarrow \mathrm{NL}$ \\
\hline $\mathrm{HU} \rightarrow \mathrm{PL}$ & $F(1,675)=2,0028$ & $(0,1575)$ & relacja jednokierunkowa \\
\hline $\mathrm{PL} \rightarrow \mathrm{HU}$ & $F(1,675)=7,7959$ & $(0,0054)$ & $\mathrm{PL} \rightarrow \mathrm{HU}$ \\
\hline $\mathrm{HU} \rightarrow \mathrm{SE}$ & $F(1,675)=0,5101$ & $(0,4754)$ & relacja jednokierunkowa \\
\hline $\mathrm{SE} \rightarrow \mathrm{HU}$ & $F(1,675)=5,6728$ & $(0,0175)$ & $\mathrm{SE} \rightarrow \mathrm{HU}$ \\
\hline $\mathrm{IT} \rightarrow \mathrm{NL}$ & $F(9,651)=2,7284$ & $(0,0039)$ & relacja dwukierunkowa \\
\hline $\mathrm{NL} \rightarrow \mathrm{IT}$ & $F(9,651)=4,6279$ & $(0,0000)$ & $\mathrm{IT} \leftrightarrow \mathrm{NL}$ \\
\hline
\end{tabular}




\begin{tabular}{|c|c|c|c|}
\hline Przyczyna $\rightarrow$ Skutek & Wartość testu & Wartość $\boldsymbol{p}$ & Wnioski \\
\hline $\mathrm{IT} \rightarrow \mathrm{PL}$ & $F(3,669)=4,6941$ & $(0,0030)$ & relacja dwukierunkowa \\
$\mathrm{PL} \rightarrow \mathrm{IT}$ & $F(3,669)=2,9116$ & $(0,0338)$ & $\mathrm{IT} \leftrightarrow \mathrm{PL}$ \\
\hline $\mathrm{IT} \rightarrow \mathrm{SE}$ & $F(7,657)=2,0919$ & $(0,0424)$ & relacja dwukierunkowa \\
$\mathrm{SE} \rightarrow \mathrm{IT}$ & $F(7,657)=3,3363$ & $(0,0017)$ & $\mathrm{IT} \leftrightarrow \mathrm{SE}$ \\
\hline $\mathrm{NL} \rightarrow \mathrm{PL}$ & $F(9,651)=2,4334$ & $(0,0100)$ & relacja jednokierunkowa \\
$\mathrm{PL} \rightarrow \mathrm{NL}$ & $F(9,651)=1,5705$ & $(0,1203)$ & $\mathrm{NL} \rightarrow \mathrm{PL}$ \\
\hline $\mathrm{NL} \rightarrow \mathrm{SE}$ & $F(10,648)=37,973$ & $(0,0000)$ & relacja dwukierunkowa \\
$\mathrm{SE} \rightarrow \mathrm{NL}$ & $F(10,648)=24,135$ & $(0,0000)$ & $\mathrm{NL} \leftrightarrow \mathrm{SE}$ \\
\hline $\mathrm{PL} \rightarrow \mathrm{SE}$ & $F(6,660)=2,1273$ & $(0,0484)$ & relacja dwukierunkowa \\
$\mathrm{SE} \rightarrow \mathrm{PL}$ & $F(6,660)=2,1708$ & $(0,0441)$ & PL $\leftrightarrow$ SE \\
\hline
\end{tabular}

Źródło: opracowanie własne.

W przypadku relacji jednokierunkowych dominowały pary zmiennych dotyczące rynków obligacji państw Europy Środkowej (CZ, HU, PL). Istotne były relacje, w których rynki z Europy Zachodniej stanowiły przyczyny dla rynków Europy Środkowej, jednak odwrotnych zależności praktycznie nie stwierdzono. Oznaczało to, że rynki Czech, Polski i Węgier były w pewnym stopniu odrębne i podatne tylko na stan koniunktury na rozwiniętych rynkach krajów Europy Zachodniej. W testach potwierdzono również istotne jednokierunkowe relacje przyczynowe niektórych państw z rynkiem greckim. W tych przypadkach przyczyną była zmienna GR potwierdzająca transmisję zmienności wywołaną kryzysem zaufania; dotyczyło to zwłaszcza państw południa Europy (ES, IT).

W przypadku większości par zmiennych testy przyczynowości potwierdziły występowanie istotnych relacji dwukierunkowych - badane europejskie rynki obligacji wykazywały współzależności świadczące o powiązaniach finansowych i gospodarczych. Można przypuszczać, że wysoki poziom integracji polityki pieniężnej i gospodarczej w Europie przyczynił się do upowszechnienia relacji między rynkami obligacji. Wpływ na obserwowane związki miał również poziom ratingu kredytowego badanych państw - różnicował on relacje między zmiennymi, co było spowodowane innymi poziomami ryzyka poszczególnych rynków. Kolejnym czynnikiem oddziałującym na obserwowane relacje był poziom integracji, zwłaszcza w przypadku państw Europy Środkowej, których ratingi były niższe niż ratingi najbezpieczniejszych krajów Europy Zachodniej i które nie prowadziły wysoce zintegrowanej polityki pieniężnej, ponieważ nie należały do strefy euro.

\section{Wyniki analizy efektu zarażania}

W celu zbadania efektu zarażania na rynku obligacji w czasie kryzysu zadłużeniowego państw europejskich oszacowano parametry modeli, których wyniki zamieszczono w Tabeli 4 . W przypadku poszczególnych rynków obligacji statystyki 
testu ilorazu wiarygodności osiągały wysokie wartości, co oznacza, że należy odrzucić hipotezę o braku wpływu zewnętrznych rynków obligacji na zmianę poziomu rentowności obligacji w danym kraju.

Mechanizm kryzysu zadłużenia polegał na jego stopniowym przenoszeniu się do kolejnych państw. Kryzys rozpoczął się od spadku zaufania do Grecji i narastających wątpliwości co do możliwości terminowej obsługi długu. Zapoczątkowało to gwałtowny wzrost rentowności obligacji i wywoływało coraz większe obawy o zdolność do obsługi długu w przypadku wielu państw strefy euro. Wahania na rynkach obligacji pokazały powiązania finansowe oraz bezpośrednie i pośrednie skutki wywołane kryzysem greckim. Analizując sposoby transmisji ryzyka na rynku długu, estymowano modele, w których zmiennymi objaśniającymi były informacje o zmianach rentowności obligacji Grecji oraz państw silnie powiązanych gospodarczo i finansowo. Wyniki oszacowań dotyczące okresu 2010-2013 ujawniły istotne relacje między zmianami rentowności obligacji w poszczególnych państwach.

W przypadku Belgii na zmiany rentowności obligacji duży wpływ miały rynki państw silnie powiązanych ekonomicznie, tj. Francji i Niderlandów, w przypadku których oszacowane parametry były najwyższe: 0,65 i 0,29 . Ponadto można było zaobserwować oddziaływanie kryzysu zadłużeniowego - istotne parametry wystąpiły w przypadku Grecji i Niemiec. Współczynnik dla Niemiec wynosił-0,22, co wskazywało na odwrotne zachowanie rentowności obligacji BE i DE i potwierdziło efekt wycofywania kapitału i lokowania go w bezpiecznych aktywach niemieckich. W przypadku rynku czeskiego nie odnotowano istotnego efektu zarażania kryzysem. Na zmiany obligacji czeskich oddziaływały zmiany rentowności długu Niemiec, Francji oraz Polski i Węgier. Wszystkie parametry modelu były dodatnie, a najwyższy występował w przypadku PL, potwierdzając występowanie silnych zależności między rynkami tego samego regionu. Zmiany rentowności obligacji Hiszpanii w największym stopniu zależne były od rynku włoskiego - współczynnik 0,84 . Istotne były również parametry odpowiadające zmianom obligacji greckich i niemieckich: $-0,03$.

Tabela 4. Oszacowane parametry funkcji zmian rentowności obligacji

Zmienna zależna (y): BE; bezwarunkowa wariancja błędu modelu $=0,000133$ Test ilorazu wiarygodności dla (G)ARCH: Chi-kwadrat $=221,298$

\begin{tabular}{|c|c|c|c|c|c|c|c|c|}
\hline $\boldsymbol{\alpha}_{\mathbf{0}}$ & $\boldsymbol{\alpha}_{\mathbf{1}}(\mathbf{D E})$ & $\boldsymbol{\alpha}_{\mathbf{2}}(\mathbf{F R})$ & $\boldsymbol{\alpha}_{\mathbf{3}}(\mathbf{G R})$ & $\boldsymbol{\alpha}_{\mathbf{4}}(\mathbf{N L})$ & $\boldsymbol{\alpha}_{\mathbf{5}}$ & $\boldsymbol{\gamma}_{\mathbf{0}}$ & $\boldsymbol{\gamma}_{\mathbf{1}}$ & $\boldsymbol{\varphi}_{\mathbf{1}}$ \\
\hline$-0,0002$ & $-0,2222$ & 0,6513 & 0,0726 & 0,2913 & - & 0,0000 & 0,0911 & 0,8795 \\
\hline$(0,4889)$ & $(0,0000)$ & $(0,0000)$ & $(0,0000)$ & $(0,0000)$ & - & $(0,0017)$ & $(0,0000)$ & $(0,0000)$ \\
\hline
\end{tabular}

Zmienna zależna $(\boldsymbol{y})$ : $\mathbf{C Z}$; bezwarunkowa wariancja błędu modelu $=0,000000$ Test ilorazu wiarygodności dla (G)ARCH: Chi-kwadrat $=307,052$

\begin{tabular}{|c|c|c|c|c|c|c|c|c|}
\hline $\boldsymbol{\alpha}_{\mathbf{0}}$ & $\boldsymbol{\alpha}_{\mathbf{1}}$ (DE) & $\boldsymbol{\alpha}_{\mathbf{2}}$ (FR) & $\boldsymbol{\alpha}_{\mathbf{3}}$ (HU) & $\boldsymbol{\alpha}_{\mathbf{4}}(\mathbf{P L})$ & $\boldsymbol{\alpha}_{\mathbf{5}}$ & $\gamma_{0}$ & $\gamma_{1}$ & $\boldsymbol{\varphi}_{\mathbf{1}}$ \\
\hline$-0,0001$ & 0,1069 & 0,0995 & 0,0597 & 0,2867 & - & 0,0000 & 0,0837 & 0,9163 \\
\hline$(0,7585)$ & $(0,0000)$ & $(0,0070)$ & $(0,0353)$ & $(0,0000)$ & - & $(0,0229)$ & $(0,0000)$ & $(0,0000)$ \\
\hline
\end{tabular}


Zmienna zależna (y): ES; bezwarunkowa wariancja błędu modelu $=0,000170$

Test ilorazu wiarygodności dla (G)ARCH: Chi-kwadrat $=286,877$

\begin{tabular}{|c|c|c|c|c|c|c|c|c|}
\hline $\boldsymbol{\alpha}_{\mathbf{0}}$ & $\boldsymbol{\alpha}_{\mathbf{1}}$ (DE) & $\boldsymbol{\alpha}_{\mathbf{2}}$ (FR) & $\boldsymbol{\alpha}_{\mathbf{3}}(\mathbf{G R})$ & $\boldsymbol{\alpha}_{\mathbf{4}}$ (IT) & $\boldsymbol{\alpha}_{\mathbf{5}}$ & $\boldsymbol{\gamma}_{\mathbf{0}}$ & $\boldsymbol{\gamma}_{\mathbf{1}}$ & $\boldsymbol{\varphi}_{\mathbf{1}}$ \\
\hline$-0,0002$ & $-0,0366$ & 0,0484 & 0,0565 & 0,8424 & - & 0,0000 & 0,1158 & 0,8710 \\
\hline$(0,5282)$ & $(0,0500)$ & $(0,0768)$ & $(0,0000)$ & $(0,0000)$ & - & $(0,0188)$ & $(0,0000)$ & $(0,0000)$ \\
\hline
\end{tabular}

Zmienna zależna $(\boldsymbol{y})$ : FI; bezwarunkowa wariancja błędu modelu $=0,000008$

Test ilorazu wiarygodności dla (G)ARCH: Chi-kwadrat $=337,308$

\begin{tabular}{|c|c|c|c|c|c|c|c|c|}
\hline $\boldsymbol{\alpha}_{\mathbf{0}}$ & $\boldsymbol{\alpha}_{\mathbf{1}} \mathbf{( \mathrm { DE } )}$ & $\boldsymbol{\alpha}_{\mathbf{2}}(\mathrm{GR})$ & $\boldsymbol{\alpha}_{\mathbf{3}}(\mathrm{SE})$ & $\boldsymbol{\alpha}_{\mathbf{4}}$ & $\boldsymbol{\alpha}_{\mathbf{5}}$ & $\gamma_{0}$ & $\gamma_{1}$ & $\boldsymbol{\varphi}_{\mathbf{1}}$ \\
\hline 0,0002 & 0,7123 & 0,0331 & 0,0770 & - & - & 0,0000 & 0,2617 & 0,7383 \\
\hline$(0,3524)$ & $(0,0000)$ & $(0,0000)$ & $(0,0000)$ & - & - & $(0,0000)$ & $(0,0000)$ & $(0,0000)$ \\
\hline
\end{tabular}

Zmienna zależna (y): FR; bezwarunkowa wariancja błędu modelu $=0,000000$

Test ilorazu wiarygodności dla (G)ARCH: Chi-kwadrat $=459,169$

\begin{tabular}{|c|c|c|c|c|c|c|c|c|}
\hline $\boldsymbol{\alpha}_{\mathbf{0}}$ & $\boldsymbol{\alpha}_{\mathbf{1}} \mathbf{( B E )}$ & $\boldsymbol{\alpha}_{\mathbf{2}}(\mathbf{D E})$ & $\boldsymbol{\alpha}_{\mathbf{3}} \mathbf{( N L )}$ & $\boldsymbol{\alpha}_{\mathbf{4}}$ & $\boldsymbol{\alpha}_{\mathbf{5}}$ & $\gamma_{0}$ & $\gamma_{1}$ & $\boldsymbol{\varphi}_{1}$ \\
\hline 0,0000 & 0,3184 & 0,1599 & 0,4017 & - & - & 0,0000 & 0,2600 & 0,7400 \\
\hline$(0,8987)$ & $(0,0000)$ & $(0,0000)$ & $(0,0000)$ & - & - & $(0,0001)$ & $(0,0000)$ & $(0,0000)$ \\
\hline
\end{tabular}

Zmienna zależna (y): HU; bezwarunkowa wariancja błędu modelu $=0,000245$

Test ilorazu wiarygodności dla (G)ARCH: Chi-kwadrat $=79,5697$

\begin{tabular}{|c|c|c|c|c|c|c|c|c|}
\hline $\boldsymbol{\alpha}_{\mathbf{0}}$ & $\boldsymbol{\alpha}_{\mathbf{1}}(\mathbf{C Z})$ & $\boldsymbol{\alpha}_{\mathbf{2}}(\mathbf{D E})$ & $\boldsymbol{\alpha}_{\mathbf{3}}(\mathbf{G R})$ & $\boldsymbol{\alpha}_{\mathbf{4}}(\mathbf{P L})$ & $\boldsymbol{\alpha}_{\mathbf{5}}$ & $\boldsymbol{\gamma}_{\mathbf{0}}$ & $\boldsymbol{\gamma}_{\mathbf{1}}$ & $\boldsymbol{\varphi}_{\mathbf{1}}$ \\
\hline$-0,0005$ & 0,0899 & $-0,0818$ & 0,0426 & 0,3330 & - & 0,0000 & 0,1346 & 0,6943 \\
\hline$(0,2072)$ & $(0,0043)$ & $(0,0000)$ & $(0,0026)$ & $(0,0000)$ & - & $(0,0001)$ & $(0,0000)$ & $(0,0000)$ \\
\hline
\end{tabular}

Zmienna zależna (y): IT; bezwarunkowa wariancja błędu modelu $=0,000262$

Test ilorazu wiarygodności dla (G)ARCH: Chi-kwadrat $=270,897$

\begin{tabular}{|c|c|c|c|c|c|c|c|c|}
\hline $\boldsymbol{\alpha}_{\mathbf{0}}$ & $\boldsymbol{\alpha}_{\mathbf{1}}$ (DE) & $\boldsymbol{\alpha}_{\mathbf{2}}(\mathbf{E S )}$ & $\boldsymbol{\alpha}_{\mathbf{3}}$ (FR) & $\boldsymbol{\alpha}_{\mathbf{4}}$ & $\boldsymbol{\alpha}_{\mathbf{5}}$ & $\boldsymbol{\gamma}_{\mathbf{0}}$ & $\boldsymbol{\gamma}_{\mathbf{1}}$ & $\boldsymbol{\varphi}_{\mathbf{1}}$ \\
\hline 0,0000 & $-0,0944$ & 0,6868 & 0,2132 & - & - & 0,0000 & 0,2587 & 0,7204 \\
\hline$(0,8044)$ & $(0,0000)$ & $(0,0000)$ & $(0,0000)$ & - & - & $(0,0017)$ & $(0,0000)$ & $(0,0000)$ \\
\hline
\end{tabular}

Zmienna zależna $(\boldsymbol{y})$ : NL; bezwarunkowa wariancja błędu modelu $=0,000158$

Test ilorazu wiarygodności dla (G)ARCH: Chi-kwadrat $=643,341$

\begin{tabular}{|c|c|c|c|c|c|c|c|c|}
\hline $\boldsymbol{\alpha}_{\mathbf{0}}$ & $\boldsymbol{\alpha}_{\mathbf{1}}$ (FR) & $\boldsymbol{\alpha}_{\mathbf{2}}$ & $\boldsymbol{\alpha}_{\mathbf{3}}$ & $\boldsymbol{\alpha}_{\mathbf{4}}$ & $\boldsymbol{\alpha}_{\mathbf{5}}$ & $\gamma_{0}$ & $\gamma_{1}$ & $\boldsymbol{\varphi}_{\mathbf{1}}$ \\
\hline$-0,0001$ & 0,9709 & - & - & - & - & 0,0000 & 0,0726 & 0,9186 \\
\hline$(0,6600)$ & $(0,0000)$ & - & - & - & - & $(0,0000)$ & $(0,0000)$ & $(0,0000)$ \\
\hline
\end{tabular}

Zmienna zależna (y): PL; bezwarunkowa wariancja błędu modelu $=0,000253$

Test ilorazu wiarygodności dla (G)ARCH: Chi-kwadrat $=388,391$

\begin{tabular}{|c|c|c|c|c|c|c|c|c|}
\hline $\boldsymbol{\alpha}_{\mathbf{0}}$ & $\boldsymbol{\alpha}_{\mathbf{1}}(\mathbf{C Z )}$ & $\boldsymbol{\alpha}_{\mathbf{2}}$ (DE) & $\boldsymbol{\alpha}_{\mathbf{3}}$ (FR) & $\boldsymbol{\alpha}_{\mathbf{4}}(\mathbf{G R})$ & $\boldsymbol{\alpha}_{\mathbf{5}}$ (HU) & $\boldsymbol{\gamma}_{\mathbf{0}}$ & $\boldsymbol{\gamma}_{\mathbf{1}}$ & $\boldsymbol{\varphi}_{\mathbf{1}}$ \\
\hline$-0,0004$ & 0,1126 & $-0,0312$ & 0,0850 & 0,0238 & 0,1199 & 0,0000 & 0,1049 & 0,8918 \\
\hline$(0,0851)$ & $(0,0000)$ & $(0,0036)$ & $(0,0000)$ & $(0,0001)$ & $(0,0000)$ & $(0,0141)$ & $(0,0000)$ & $(0,0000)$ \\
\hline
\end{tabular}

Zmienna zależna (y): SE; bezwarunkowa wariancja błędu modelu $=0,000219$

Test ilorazu wiarygodności dla (G)ARCH: Chi-kwadrat $=253,514$

\begin{tabular}{|c|c|c|c|c|c|c|c|c|}
\hline $\boldsymbol{\alpha}_{\mathbf{0}}$ & $\boldsymbol{\alpha}_{\mathbf{1}}(\mathbf{D E})$ & $\boldsymbol{\alpha}_{\mathbf{2}}(\mathbf{F I})$ & $\boldsymbol{\alpha}_{\mathbf{3}}(\mathbf{G R})$ & $\boldsymbol{\alpha}_{\mathbf{4}}$ & $\boldsymbol{\alpha}_{\mathbf{5}}$ & $\boldsymbol{\gamma}_{\mathbf{0}}$ & $\boldsymbol{\gamma}_{\mathbf{1}}$ & $\boldsymbol{\varphi}_{\mathbf{1}}$ \\
\hline 0,0001 & 0,4930 & 0,2056 & $-0,0632$ & - & - & 0,0000 & 0,0772 & 0,9079 \\
\hline$(0,6922)$ & $(0,0000)$ & $(0,0000)$ & $(0,0000)$ & - & - & $(0,0023)$ & $(0,0000)$ & $(0,0000)$ \\
\hline
\end{tabular}

W nawiasach wartość $p$.

Źródło: opracowanie własne. 
W przypadku obligacji Finlandii dominował wpływ rynku niemieckiego: parametr 0,71 . Duży wpływ miały na nie również obligacje szwedzkie, co świadczy o silnych relacjach regionalnych. Mimo wysokiego ratingu inwestycyjnego Finlandii istotny okazał się także wpływ zmian obligacji greckich, ale jego współczynnik był niski: 0,03 . Zmiany rentowności obligacji francuskich były istotnie zależne od rynków obligacji najbliższych sąsiadów: NL, BE i DE, co wskazuje na silne powiązania finansowe między tymi rynkami. Rynek obligacji węgierskich zależny był w największym stopniu od zmian obligacji państw regionu (PL, HU). Ponadto istotny był wpływ kryzysu - dodatni współczynnik GR i ujemny w przypadku DE. Na obligacje włoskie silnie oddziaływały obligacje hiszpańskie $(0,68)$ i francuskie $(0,21)$, co potwierdziło powiązania między rynkami długu Hiszpanii i Włoch. Oddziaływanie kryzysu nie było tak jednoznaczne, jak w przypadku innych państw, ale jego wpływ był wyraźny. Istotny był ujemny współczynnik w przypadku DE, pozwalający przyjąć założenie o wycofywaniu kapitału z obligacji włoskich oraz ich przepływie do bezpiecznych obligacji niemieckich. Zmiany obligacji Niderlandów były silnie uzależnione jedynie od zmian obligacji francuskich, co korespondowało z obserwacjami dotyczącymi długu Francji. Jeśli chodzi o obligacje polskie, to oszacowania skłaniały do podobnych wniosków, jak w przypadku długu węgierskiego. Najsilniejszy wpływ na zmiany rentowności miały rynki regionu, a ponadto odnotowano istotny współczynnik dla GR i ujemny współczynnik dla DE. Zmiany rynku obligacji szwedzkich były silnie uzależnione od DE, FI i GR. Parametry modelu wskazywały, że dług Szwecji pełnił podobną funkcję jak dług Niemiec, które były miejscem bezpiecznego lokowania aktywów w okresie niesprzyjającym ryzyku. Potwierdzono również obserwowane wcześniej relacje między rynkami regionu.

Podsumowując przegląd estymowanych modeli, można stwierdzić, że na większość badanych rynków istotny wpływ miały zmiany rentowności obligacji greckich, co wskazuje na efekt zarażania kryzysem. Dotyczyło to zwłaszcza krajów o niższych ratingach inwestycyjnych (patrz: załącznik). Niemiecki rynek obligacji był miejscem bezpiecznej realokacji kapitału. Ujemne wartości współczynników w modelach wskazywały na wycofywanie środków z rynku długu części państw, najczęściej o niższych ratingach, a następnie na inwestowanie ich w bezpieczne obligacje niemieckie. Można było również dostrzec istotne relacje między zmianami rentowności obligacji państw tego samego regionu, co oznaczało, że lokujący kapitał inwestorzy posługują się również kryterium geograficznym oraz podobieństwem rynków, biorąc pod uwagę wzajemne relacje gospodarcze i finansowe poszczególnych państw. 


\section{Podsumowanie}

Przeprowadzone badania współzależności między rynkami obligacji skarbowych w Europie potwierdziły występowanie istotnych relacji w analizowanych okresach, jednak relacje te były zróżnicowane i uzależnione od poszczególnych rynków.

Testy przyczynowości w sensie Grangera wykorzystujące dwuwymiarowe modele wektorowej autoregresji nie dały podstaw do odrzucenia hipotezy badawczej (H1) o występowaniu istotnych relacji. W wynikach badań dominowały dwukierunkowe relacje między rynkami obligacji, zwłaszcza w przypadku rozwiniętych państw Europy Zachodniej. Świadczyło to o wysokim poziomie integracji gospodarczej i finansowej. Wydaje się również, że kluczową rolę odgrywała tutaj skoordynowana polityka pieniężna w ramach unii walutowej. Otrzymane wyniki były w dużym stopniu zgodne z wynikami badań Gomez-Puig i Sosvilla-Rivery (2014), w których podkreślano występowanie licznych relacji przyczynowych. Dwukierunkowe relacje między wieloma rynkami potwierdzili również Babalos $\mathrm{i}$ in. (2015). Kolejnym czynnikiem wpływającym na wystąpienie i kierunek relacji przyczynowych był poziom ratingu kredytowego - im niższy rating, tym więcej relacji jednokierunkowych lub brak relacji między parami badanych zmiennych. Korespondowało to również z badaniami Babalosa i in. (2015), w których wskazywano na słabe relacje między rynkami południa i północy Europy. Oprócz ryzyka istotne znaczenie miał także poziom integracji. Państwa Europy Środkowej pozostające poza strefą euro prowadziły niezależną politykę pieniężną, co mogło wpływać na kierunek zależności. Słabsze relacje w przypadku nowych rynków UE dostrzegli już Kim i in. (2005). W przypadku Czech, Polski i Węgier dominowały przyczynowe relacje jednokierunkowe, w których przyczyną była zmienna odpowiadająca rozwiniętemu rynkowi. Potwierdzało to występowanie przepływu informacji z krajów głównych do krajów peryferyjnych Unii Europejskiej, co podkreślali w badaniach Babalos i in. (2015).

Przedmiotem badania był również efekt zarażania w trakcie tzw. kryzysu greckiego. Otrzymane wyniki nie pozwoliły na odrzucenie hipotezy badawczej (H2) o transmisji zmian rentowności na rynkach obligacji skarbowych. W większości przypadków estymowane modele potwierdziły, że wpływ zmian rentowności obligacji greckich był statystycznie istotny, a tym samym wskazały one na efekt zarażania. Bezpośredni wpływ kryzysu greckiego na wzrost wymaganych rentowności obligacji dotyczył głównie państw o niższych ratingach kredytowych. Znalazło to potwierdzenie również w innych badaniach - Arghyrou i Kontonikas (2012) twierdzili, że efekt zarażania dotyczył głównie państw peryferyjnych EMU, a Metiu (2012) wskazywał na państwa południa Europy. W przypadku państw z najwyższymi ratingami, a zwłaszcza Niemiec, obserwowano pośredni wpływ kryzysu zaufania w strefie euro. Wycofywanie kapitału z państw 
uważanych za ryzykowne spowodowało skokowy wzrost rentowności obligacji, ale z drugiej strony - spadek rentowności w krajach uznawanych za bezpieczne. Wzmożony napływ środków od inwestorów poszukujących bezpieczeństwa i płynności wpływał na wzrosty cen obligacji i spadki ich rentowności. Korespondowało to z wnioskami Bernoth i Erdogan (2012), które podkreślały rolę Niemiec jako miejsca bezpiecznej alokacji aktywów. Metiu (2012) oraz Beetsma i in. (2013) również wskazywali, że główne gospodarki Europy były mniej podatne na efekt zarażania. Przeprowadzone testy potwierdziły ponadto relacje między zmianami rentowności obligacji państw z tego samego regionu. Wskazywało to na siłę wzajemnych relacji gospodarczych oraz kryterium geograficzne i podobieństwa rynków jako klucz alokacji kapitału w skali międzynarodowej.

Wyniki badań wpisują się w dotychczasową dyskusję naukową oraz poszerzają zasób informacji dla organów regulacyjnych i badaczy zainteresowanych problematyką rynku długu w unii gospodarczej i walutowej.

\section{Bibliografia}

Afonso A., Arghyrou M., Bagdatoglou G., Kontonikas A. (2015), On the time-varying relationship between EMU sovereign spreads and their determinants, „Economic Modelling”, 44.

Arghyrou M.C., Kontonikas A. (2012), The EMU sovereign-debt crisis: Fundamentals, expectations and contagion, ,Journal of International Financial Markets, Institutions \& Money", 22.

Babalos V., Kyei C., Poutos E.I. (2015), Causality and Contagion in EMU Sovereign Bonds Revisited: Novel Evidence from Nonlinear Causality Tests, „Working Papers" 14, University of Pretoria, Department of Economics.

Beetsma R., Giuliodori M., Jong F., Widijanto D. (2013), Spread the news: The impact of news on the European sovereign bond markets during the crisis, „Journal of International Money and Finance”, 34.

Bernoth K., Erdogan B. (2012), Sovereign bond yield spreads: A time-varying coefficient approach, „Journal of International Money and Finance”, 31.

Bernoth K., Hagen J., Schuknecht L. (2012), Sovereign risk premiums in the European government bond market, ,Journal of International Money and Finance", 31.

Bieńkowski W., Gawrońska-Nowak B., Grabowski W. (2011), Podatność polskich rynków finansowych na niestabilności wewnętrzne i zewnętrzne, „Materiały i Studia", 258, Narodowy Bank Polski.

Brzeszczyński J., Kelm R. (2002), Ekonometryczne modele rynków finansowych, WIG-Press, Warszawa. 
Burzała M. (2015), Zmiana wartości oczekiwanej $i$ wariancji stóp zwrotu z indeksów giełdowych $w$ czasie kryzysu. Zarażanie czy wzajemne zależności rynków kapitałowych? „Zeszyt Naukowe Uniwersytetu Szczecińskiego, Finanse, Rynki Finansowe, Ubezpieczenia", 75.

Clare A., Lekkos I. (2000), An analysis of the relationship between international bond markets, „Working paper”, Bank of England.

Dickey D.A., Fuller W.A. (1979), Distribution of the estimators for autoregressive time-series with a unit root, ,Journal of the American Statistical Association", 74.

Ejsing J., Lemke W. (2009), The Janus-headed salvation: Sovereign and bank credit risk premia during 2008-2009, „Working Paper” 1127, European Central Bank.

Engle R.F., Granger C.W.J. (1987), Co-integration and error correction: Representation, estimation and testing, „Econometrica”, 55.

Gennaioli N., Martin A., Rossi S. (2014), Sovereign default, domestic banks and financial institutions, „Journal of Finance”, 69.

Gomez-Puig M., Sosvilla-Rivero S. (2014), Causality and contagion in EMU sovereign debt markets, „International Review of Economics \& Finance”, 33.

Gorea D., Radev D. (2014), The euro area sovereign debt crisis: Can contagion spread from the periphery to the core? „International Review of Economics and Finance", 30.

Granger C.W.J. (1969), Investigating causal relations by econometric models and cross-spectral methods, „Econometrica”, 37.

Kalbaska A., Gatkowski M. (2012), Eurozone sovereign contagion: Evidence from the CDS market (2005-2010), „Journal of Economic Behaviour and Organization", 83.

Karkowska R. (2015), The application of GARCH(1,1) model for measuring shocks transmission in bond market, „Acta Universitatis Lodziensis. Folia Oeconomica", 3(314).

Kim S.J., Lucey B.M., Wu E. (2005), Dynamics of Bond Market Integration between Established and New European Union Countries, „Journal of International Financial Markets, Institutions and Money", 16.

Kwiatkowski D., Phillips P.C.B., Schmidt P., Shin Y. (1992), Testing the null hypothesis of stationarity against the alternative of a unit root: How sure are we that economic time series have a unit root?, „Journal of Econometrics", 54.

Maltritz D. (2012), Determinants of sovereign yield spreads in the Eurozone: A Bayesian approach, ,Journal of International Money and Finance”, 31.

Metiu N. (2012), Sovereign risk contagion in the Eurozone, „Economics Letters”, 117.

Syllignakis M.N., Kouretas G.P. (2011), Dynamic correlation analysis of financial contagion: Evidence from the Central and Eastern European markets, „International Review of Economics and Finance”, 20. 


\section{Streszczenie}

Artykuł analizuje relacje między wybranymi rynkami obligacji skarbowych w Europie. Badanie koncentruje się na dwóch okresach: od stycznia 2006 r. do grudnia 2018 r. i od stycznia 2010 r. do grudnia 2013 r. W przypadku pierwszego okresu zastosowano dwuwymiarowy model autoregresji wektorowej z danymi tygodniowymi. Wyniki empiryczne wskazały na dwukierunkowe relacje między rynkami rozwiniętymi i jednokierunkową przyczynowość w przypadku Grecji i Europy Środkowej. Badania nad drugim okresem, dotyczące kryzysu finansów publicznych Grecji, miały na celu przeanalizowanie tzw. efektu zarażania na rynku obligacji skarbowych, a ich wyniki potwierdziły występowanie efektu zarażania w przypadku państw o niskim ratingu kredytowym.

Slowa kluczowe: rynek obligacji, efekt zarażania, przyczynowość w sensie Grangera, kryzys finansowy

JEL: C32, G01, G15

\section{Summary}

\section{Causality analysis and contagion effect on the treasury bond market}

The paper examines relationships between selected treasury bond market in Europe. The study focuses on two periods: from January 2006 to December 2018 and from January 2010 to December 2013. For the first period bivariate vector autoregressive model was used with weekly data. The empirical results indicated bidirectional relationships for developed markets and unidirectional causality for Greece and Central Europe. The second period concerns the crisis of public finances in Greece. In this case, the aim of the study was to determine the so-called contagion effect in treasury bonds market. The analysis confirmed the contagion effect for countries with low credit ratings.

Keywords: bond market, contagion effect, Granger causality, financial crisis 


\section{Załącznik}

Tabela 5. Ratingi kredytowe badanych państw (stan z grudnia 2012 r.)

\begin{tabular}{|l|c|c|c|}
\cline { 2 - 4 } \multicolumn{1}{c|}{} & Fitch & Moody's & S\&P \\
\hline Belgia (BA) & AA & Aa3 & AA \\
\hline Czechy (CZ) & A+ & A1 & AA- \\
\hline Niemcy (DE) & AAA & Aaa & AAA \\
\hline Hiszpania (ES) & BBB & Baa3 & BBB- \\
\hline Finlandia (FI) & AAA & Aaa & AAA \\
\hline Francja (FR) & AAA & Aa1 & AA+ \\
\hline Grecja (GR) & CCC & C & B- \\
\hline Węgry (HU) & BB + & Ba1 & BB \\
\hline Włochy (IT) & A- & Baa2 & BBB + \\
\hline Niderlandy (NL) & AAA & Aaa & AAA \\
\hline Polska (PL) & A- & A2 & A- \\
\hline Szwecja (SE) & AAA & Aaa & AAA \\
\hline
\end{tabular}

Źródło: tradingeconomics. 